\title{
Regression model analysis for prediction of body weight from body measurements in female Batur sheep of Banjarnegara District, Indonesia
}

\author{
ALEK IBRAHIM ${ }^{1, \vartheta}$, WAYAN TUNAS ARTAMA ${ }^{2}$, I GEDE SUPARTA BUDISATRIA ${ }^{3}$, RIDWAN YUNIAWAN ${ }^{3}$, \\ BAYU ANDRI ATMOKO ${ }^{3}$, RINI WIDAYANTI',v \\ ${ }^{1}$ Doctoral Program in Veterinary Science, Faculty of Veterinary Medicine, Universitas Gadjah Mada. Jl. Fauna No.2, Karangmalang, Sleman 55281, \\ Yogyakarta, Indonesia. Tel.: +62-274-6492088/560862, Fax.: +62-274-560861, `email: alek.ibrahim@mail.ugm.ac.id \\ ${ }^{2}$ Department of Biochemistry and Molecular Biology, Faculty of Veterinary Medicine, Universitas Gadjah Mada. J1. Fauna No.2, Karangmalang, Sleman \\ 55281, Yogyakarta, Indonesia \\ ${ }^{3}$ Department of Animal Production, Faculty of Animal Science, Universitas Gadjah Mada. J1. Fauna No. 2, Karangmalang, Sleman 55281, Yogyakarta, \\ Indonesia. Tel.: +62-274-6492088/560862, Fax.: +62-274-560861, ^`email: rini_widayanti@ugm.ac.id
}

Manuscript received: 27 April 2021. Revision accepted: 15 June 2021.

\begin{abstract}
Ibrahim A, Artama WT, Budisatria IGS, Yuniawan R, Atmoko BA, Widayanti R. 2021. Regression model analysis for prediction of body weight from body measurements in female Batur sheep of Banjarnegara District, Indonesia. Biodiversitas 22: 27232730. Bodyweight is an important aspect of livestock management. The present study was undertaken to estimate correlation coefficients between biometric traits and identify best predictor of body weight in female Batur sheep from body measurements. Data on body weight and body measurements (body length: BL, chest girth: CG and withers height: $\mathrm{WH}$ ) were collected from 73 female Batur sheep in Batur Village, Banjarnegara District, Central Java Province, Indonesia. Batur sheep were grouped into 3 categories based on their age, namely groups $<1.5$ years, $1.5-2.5$ years and $>2.5$ years. The data were analyzed using simple, multiple, and automatic linear regression methods using the SPSS computer software version 25 platform. The correlation coefficient, coefficient determination, adjusted coefficient determination, residual standard error, Akaike information criterion, Bayesian information criterion, and Akaike information criterion corrected were used to determine the best regression formula for the prediction of BW. The average BW (kg), BL $(\mathrm{cm})$, CG $(\mathrm{cm})$, and WH $(\mathrm{cm})$ of $49.27,63.11,91.41$, and 56.82, respectively was observed in the present study. The correlation coefficients of $0.433,0.866$, and 0.369 for BW with BL, CG, and WH were observed in the present study. The best prediction of BW using two predictors $(\mathrm{BL}$ and $\mathrm{GC}$ ) was $\mathrm{BW}=-56.522+0.509 \mathrm{BL}+0.843 \mathrm{CG}$, followed by using three predictors $(\mathrm{BL}, \mathrm{CG}$, and $\mathrm{WH})$ was $\mathrm{BW}=-57.897+0.505 \mathrm{BL}+0.839 \mathrm{CG}+0.034 \mathrm{WH}$, and using the only one predictor $(\mathrm{CG})$ was $\mathrm{BW}=-28.443+0.905 \mathrm{CG}$. The study revealed that CG and its combination with other linear body measurements can effectively define the body weight in Batur sheep. However, the highest $\mathrm{R}^{2}$ of 0.782 was observed when $\mathrm{CG}$ and $\mathrm{BL}$ were used as predictors.
\end{abstract}

Keywords: Batur sheep, body size, linear regression, phenotypic characteristics, prediction model

\section{INTRODUCTION}

Batur sheep are one of the Indonesian neighborhood sheep breeds with a unique geographical distribution in upland areas, namely Banjarnegara District, Central Java, Indonesia (Ibrahim et al. 2020b). Batur sheep are designated as one of the local Indonesian sheep breeds based on the Decree of the Minister of Agriculture of the Republic of Indonesia No. 2916/Kpts/OT.140/6/2011. According to (Ministry of Agriculture 2011; Ibrahim et al. 2020a) Batur sheep crossbred sheep developed by crossing thin-tailed sheep and Merino sheep. Sodiq et al. (2011) stated that Batur is suitable for upland areas with cold and humid environmental conditions, i.e., in Banjarnegara District, Indonesia.

The demand for Batur sheep continues to increase every year. However, the population of Batur sheep in the Banjarnegara District was declining $15 \%$ during the last 5 years (Department of Agriculture Fisheries and Animal Husbandry 2019). Various efforts have been made by the Animal Husbandry Service and the local government to increase the population of Batur sheep. The Batur Village has the highest number of sheep farmers and Batur sheep population as compared to other villages in Banjarnegara District with $29.83 \%$ of farmers and having $36.06 \%$ of Batur sheep population (Muryanto et al. 2019). The body measurement will also be used for genetic selection to enhance Batur sheep growth performance (Dakhlan et al. 2020; Waheed et al. 2020). Body measurement in farm animals also is used for visible identity and to decide its growth pattern (Ullah et al. 2013; Ghahri et al. 2019; Waheed et al. 2020).

Bodyweight determines livestock value, especially in the selection program, breeding program, fattening program, meat and carcass characterizations, and marketing (Hossein-Zadeh 2012; Abdel-Mageed and Ghanem 2013; Eteqadi et al. 2014; Jafari and Hashemi 2014; Mulyono et al. 2018; Ibrahim et al. 2019a, b; Ruangwittayanusorn et al. 2019; Dakhlan et al. 2020). Bodyweight is also used to determine livestock management, such as feeding, medicine doses, slaughter time, and evaluating growth (Mekuriaw et al. 2013; Ullah et al. 2013; Ghahri et al. 
2019; Iqbal et al. 2019; Ibrahim et al. 2020b). The weighing of livestock is the most accurate method of body weight estimation. However, in smallholder farms not having scales or good construction pens body weight measurement will be difficult. Therefore, estimating body weight from body measurements can use an alternative (Koc et al. 2017). Several studies reported a close accord between body weight and body measurements in sheep and goat (Mohammad et al. 2012; Eyduran et al. 2017; Dakhlan et al. 2020, 2021; Sabbioni et al. 2020; Rather et al. 2021).

The studies on the prediction of body weight using body size in sheep have been carried out by many researchers (Yakubu 2012; Ravimurugan et al. 2013; Yilmaz et al. 2013; Abera et al. 2014; Saghi et al. 2018; Iqbal et al. 2019; Arsalan et al. 2021; Rather et al. 2021). Predicting body weight using body measurements is considered simpler than weighing the livestock, especially in smallholder farms. Therefore, the present study was undertaken to estimate correlation and regression models and determined the best regression formula for the prediction of body weight in female Batur sheep using body measurements kept by smallholder farmers.

\section{MATERIALS AND METHODS}

This study was approved by the Animal Care and Use Committee of the Faculty of Veterinary Medicine, Universitas Gadjah Mada, with the ethical clearance number 002/EC-FKH/Int/2019, and the National Political and Unity of Yogyakarta Special Region with the approval number 074/1850/Kesbangpol/2019. This research has been done in November 2019-April 2020 located in Batur Village, Batur Sub-district, Banjarnegara District, Central
Java Province, Indonesia. Batur Village, located at the longitude and latitude coordinates of $7^{\circ} 13^{\prime} 59.9^{\prime \prime S}$ $109^{\circ} 47^{\prime} 34.7^{\prime \prime E}-7^{\circ} 11^{\prime} 02.1^{\prime \prime S} 109^{\circ} 49^{\prime} 32.1^{\prime \prime E}$, has an area of 1,212.42 ha, and an altitude of 1,666 $\mathrm{m}$ above sea level. This area has a temperature of $14-20^{\circ} \mathrm{C}$, humidity of 84 $85 \%$, and rainfall of $2,238 \mathrm{~mm} / \mathrm{year}$. This village is relatively cold for a tropical area; the majority of the local communities create horticultural lands and plantations (Central Bureau of Statistics 2016). The location of data collection was shown in Figure 1. Smallholder farmers carried out the majority of the Batur Sheep farming system with the traditional system as secondary farming activity. Sheep were kept intensively in colony cages. The feed was provided 2-3 times per day with forages infield grass and vegetable farming by-products such as carrots, and cabbage leaves. The concentrate feeds, and drinking water was rarely provided.

The research was carried out using a survey method. The determination of the Batur sheep was through phenotypic characteristics based on the Decree of the Ministry of Agriculture of the Republic of Indonesia No. 2916/Kpts/OT.140/6/2011 (Ministry of Agriculture 2011). The age of the Batur Sheep was determined based on records and direct information from the farmers and dentition. A total of 73 female Batur sheep kept by smallholder farmers were selected for this research and analysis. Batur sheep were grouped into 3 categories based on their age, namely groups $<1.5$ years, $1.5-2.5$ years, and $>2.5$ years. The Batur sheep were weighed with balance Camry $^{\odot}$ with the capacity of $150 \mathrm{~kg}$, and accuracy of 0.01 $\mathrm{kg}$, and their body measurement were measured with Butterfly ${ }^{\odot}$ measuring tape with an accuracy of $0.1 \mathrm{~cm}$. The body measurement scheme showed in Figure 2.

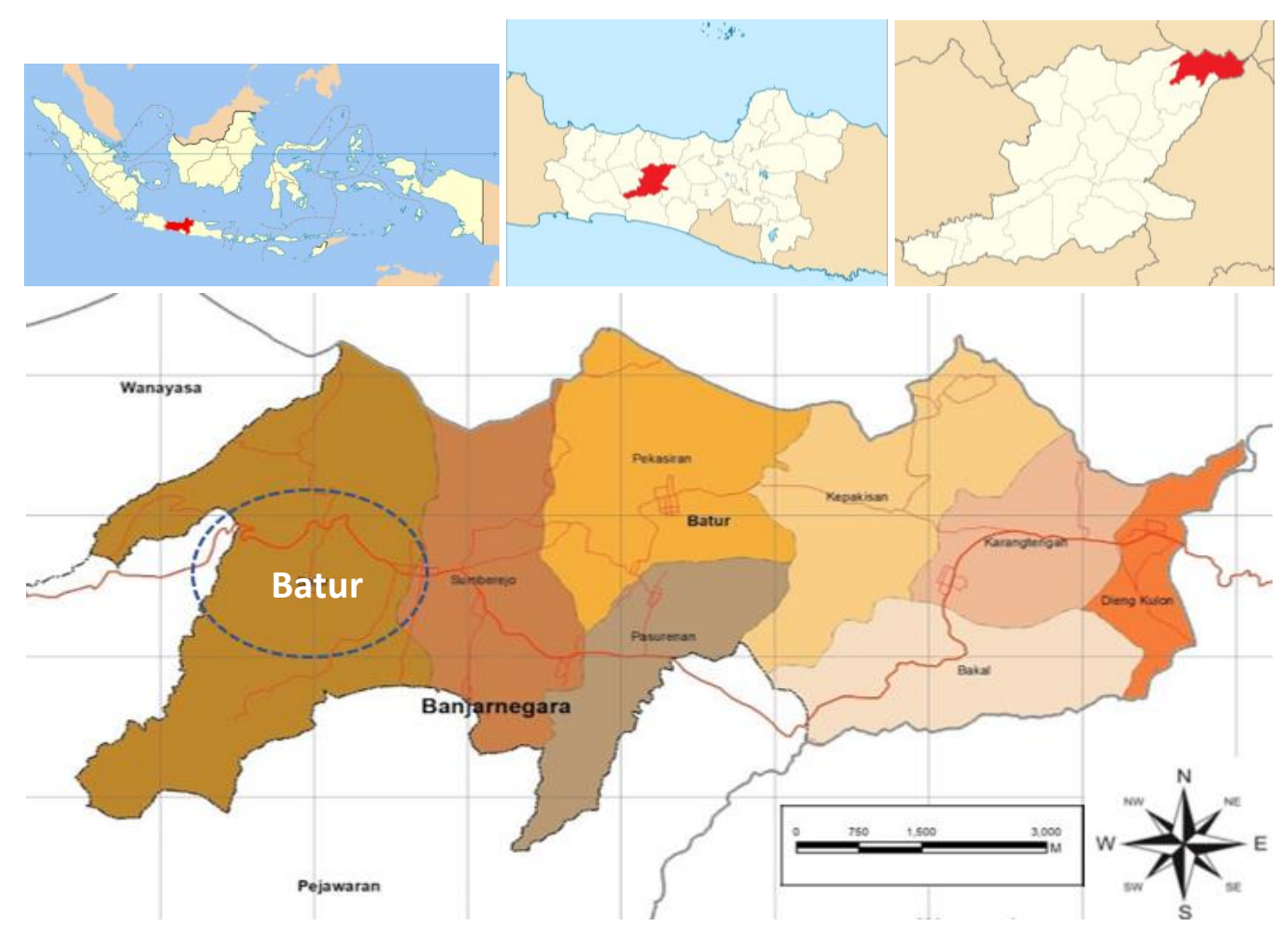

Figure 1. Location of Batur Village (gray circle), Batur Sub-district, Banjarnegara District, Central Java Province, Indonesia 


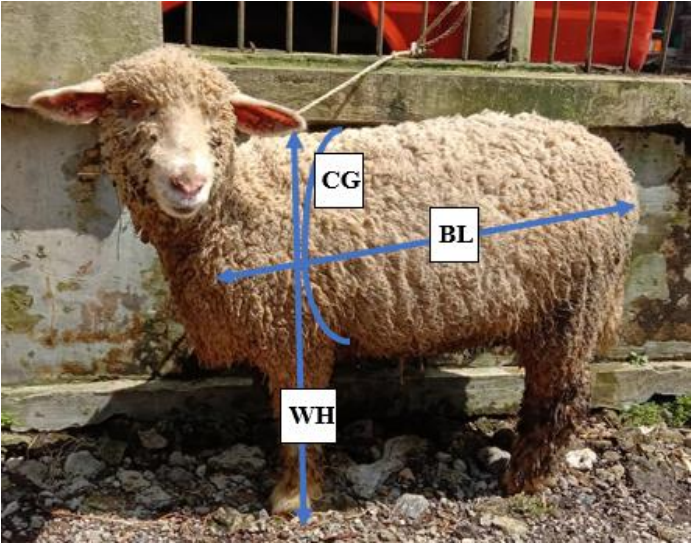

Figure 2. The body measurements scheme of body length (BL), chest girth (CG), and withers height (WH) in female Batur sheep

Data analysis was performed using the SPSS version 25 platform (IBM Inc., USA). The normality of the data distribution was checked using the boxplot and the Kolmogorov-Smirnov and Shapiro test. Correlation between variables was calculated using Pearson correlation. The simple and multiple linear regression models were used to investigate the relationship between body measurements and body weight. The generalized linear mixed models method is used to determine the value of Akaike information criterion (AIC) and Bayesian information criterion (BIC). Based on the regression model with the highest $r, R^{2}$, adjusted $R^{2}$, and the lowest RSE, AIC, and BIC were recommended to estimate the Batur sheep BW (Dakhlan et al. 2020). The fittest models are also performed using automatic linear modeling with best subsets and forward stepwise methods using Akaike information criterion corrected (AICC) (Cleophas and Zwinderman 2016)

\section{RESULTS AND DISCUSSION}

\section{Body measurements}

The body weight and body measurements of female Batur sheep based on the aged category were shown in Table 1 and Figure 3 . The data were stratified by age $(<1.5$ years, 1.5-2.5 years, and >2.5 years). Based on these data, it can be seen that age matters to most of the body measurements parameter; the younger sheep showed smaller body measurements than elder sheep. Ibrahim et al. (2020b) reported that the body weight and withers height of adult (2-4 years old) female Batur sheep significantly higher than the young (1-2 years old) female Batur sheep, namely the BW was 64.37 and $63.12 \mathrm{~kg}$, the $\mathrm{WH}$ was 62.08 and $59.48 \mathrm{~cm}$. The standard deviation in the younger age category (Table 1) is also relatively higher than elder sheep. It can be influenced by differences in their genetic potential to grow because environmental factors such as feeding management and maintenance are relatively similar. Thus, a high variation in BW can be used as a good indicator of the success of the selection program (Dakhlan et al. 2021). Figure 3 showed that the BW had been normally distributed. There were no outliers in the analyzed data.

Table 1. The mean and standard deviation of the bodyweight and body measurements in female Batur sheep based on aged category

\begin{tabular}{lccccc}
\hline \multicolumn{1}{c}{ Age } & N & Body weight $(\mathbf{k g})$ & Body length $(\mathbf{c m})$ & Chest girth $(\mathbf{c m})$ & Withers height $(\mathbf{c m})$ \\
\hline$<1.5$ years & 28 & $57.37 \pm 17.99$ & $65.28 \pm 7.34$ & $94.07 \pm 16.24$ & $59.58 \pm 6.62$ \\
1.5-2.5 years & 29 & $64.44 \pm 15.50$ & $68.56 \pm 5.23$ & $104.48 \pm 15.25$ & $61.30 \pm 5.07$ \\
$>2.5$ years & 22 & $69.50 \pm 17.06$ & $69.39 \pm 6.08$ & $106.64 \pm 16.07$ & $62.40 \pm 5.64$ \\
\hline
\end{tabular}

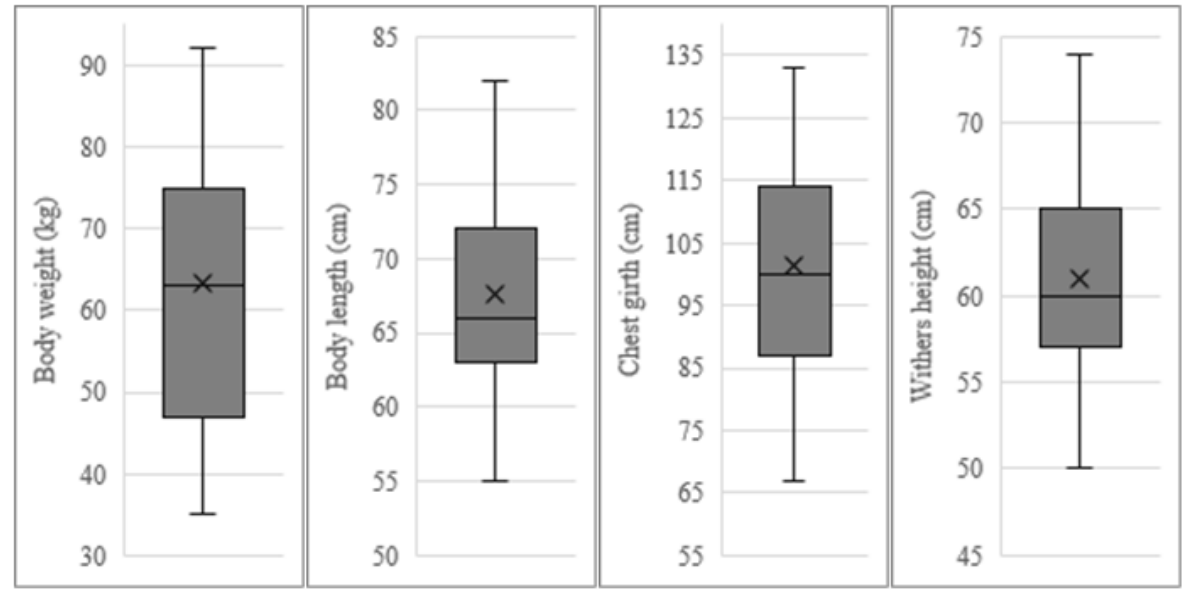

Figure 3. Boxplot of body weight and body measurements of female Batur sheep aged 1.5-4 years 
In this study, adult female Batur sheep aged $<1.5,1.5-2$, and $>2.5$ years old had an average of 57.37, 64.44, and $69.50 \mathrm{~kg}$, respectively. $69.50 \mathrm{~kg}$. The trait presented an increasing trend with an increase in age with lowest and highest at extreme ages (Table 1). However, a higher average body weight of $82.00 \mathrm{~kg}$ was observed in adult female Batur sheep (Ministry of Agriculture 2011). Haren et al. (2018) reported 25.35, 47.67, and $69.10 \mathrm{~kg}$ body weights at 6,12 , and 24 months in female Batur sheep. Lower estimates of $8.47 \mathrm{~kg}, 16.48 \mathrm{~kg}$, and $24.63 \mathrm{~kg}$ in Zulu sheep at age <3 months, 3-6 months and >6 months, respectively (Mavule et al. 2013), $36.03 \mathrm{~kg}$ at 12 months Mergali sheep (Tariq et al. 2013), 16.11-20.06 kg at 3-6 months in female Guilan sheep (Eteqadi et al. 2014), 26-28 $\mathrm{kg}$ in adult female Javanese fat-tailed sheep (Udo and Budisatria 2011), 26.21 kg in adult female Nigerian sheep (Mahmud et al. 2014), $29.82 \mathrm{~kg}$ in adult female blackhead Somali sheep (Feyissa et al. 2018), $25.21 \mathrm{~kg}$ in adult female Holla sheep (Kefale et al. 2017) and $35.72 \mathrm{~kg}$ and $42.48 \mathrm{~kg}$ in female Wonosobo sheep aged 6-12 months and $>36-48$ months, respectively (Haryanti et al. 2015). Figure 3 showed that all body measurements of female Batur sheep had been normally distributed and there were no outliers in the data.

The BL (Table 1) showed an increase in line with an increase in age. However, higher estimates of 51.67, 66.56, and $71.70 \mathrm{~cm}$ in 6,12 , and 24 months age groups (Haren et al. 2018). Lower estimates of $71,43 \mathrm{~cm}$ for the trait were also observed in Karya sheep aged 24 months (Yilmaz et al. 2013). However, higher estimate 65.25, 67.57, 67.95 and $68.97 \mathrm{~cm}$ at $>12-18,>18-24,>24-36$ and $>36-48$ months in the female Wonosobo sheep, respectively (Haryanti et al. 2015). The trait in Makuie sheep at 24 months of age was $49.4 \mathrm{~cm}$ (Jafari and Hashemi 2014) and adult Garut sheep was $76.35 \mathrm{~cm}$ (Rohayati and Herawati 2020). The $C G$ in the current study was higher than reported in previous studies. Haren et al. (2018) reported CG in female Batur sheep was 69.80, 81.50, and $94.90 \mathrm{~cm}$ at 6,12 , and 24 months age, respectively. The CG of 79.11, $76.51,77.61,81.11$, and $80.47 \mathrm{~cm}$ at $>6-12,>12-18,>18-$ $24,>24-36$, and >36-48 months age in Wonosobo female sheep was reported by Haryanti et al. (2015), and Feyissa et al. (2018) reported CG of $72.44 \mathrm{~cm}$ in adult female blackhead Somali sheep. However, Jafari and Hashemi (2014) in Makuie, sheep aged 24 and 36 months were 81.2 and $82.6 \mathrm{~cm}$, respectively. The estimate for $\mathrm{WH}$ observed in the present study was in close consonance equal to the findings of Haren et al. (2018) at the age of 6, 12, and 24 months with estimates of 51.47, 59.17, and $61.5 \mathrm{~cm}$, respectively. However, the estimate of $80.19 \mathrm{~cm}$ for $\mathrm{WH}$ in fight Garut sheep was observed by Rohayati and Herawati (2020). Hailu et al. (2020) in Tahtay Maichew indigenous sheep, and Jafari and Hashemi (2014) in Makuie sheep, found WH of $62.00 \mathrm{~cm}$ and $67.58 \mathrm{~cm}$, respectively. Shirzeyli et al. (2013) in Shaal sheep, Macoeci sheep, and Zandi sheep found CG of $69.25 \mathrm{~cm}, 74.23 \mathrm{~cm}$, and 76.54 $\mathrm{cm}$, respectively.

In contrast, Ravimurugan et al. (2013) in Kilakarsal sheep and Rather et al. (2021) in Kashmir Merino sheep found $\mathrm{CH}$ of $69.74 \mathrm{~cm}$ and 37.03 inches, respectively.
These differences can be influenced by the breed the environment and the management practices in vogue. The BW and body measurements in sheep were strongly influenced by environmental factors, which will result in varying body measurements even in the same breed (Dakhlan et al. 2021).

\section{Correlation between body measurements and body weight}

The correlation analysis of body measurements of female Batur sheep was not performed in a separate group of age. The results in this study indicate that body measurement has a positive correlation with $\mathrm{BW}$. The $\mathrm{CG}$ (0.836) had the highest correlation with BW, followed by BL (0.443) and WH (0.369). The correlation between body measurements was also showed positive. The correlation between CG and WH was the highest (0.390), following by between BL and CG (0.315) and between BL and WH was the lowest $(0.242)$. This result was aligned with the previous research of Mohammad et al. (2012) on Pakistan indigenous sheep, Mavule et al. (2013) on Zulu sheep, Waheed et al. (2020) on Beetal goats, Haq et al. (2020) on Jabres cattle, and Rather et al. (2021) in Kashmir Merino sheep. The correlation between the independent variables was less than 0.90 , indicating no multicollinearity. Multicollinearity is a phenomenon when two or more predictors are correlated. If it happens, the standard error of the coefficients will increase, which means that the coefficients for some or all of the independent variables can be a significant difference from 0 . One sign of multicollinearity is the correlation between producers is large. Multicollinearity can make some variables not statistically significant even though they should be significant. It will affect the predictors that influence the model created (Khan et al. 2014; Daoud 2017; Lavery et al. 2017). According to Guilford's rules, the correlation coefficient (r) $0.0-0.70$ was a moderate correlation (substantial relationship), 0.70-0.90 was a high correlation (significant relationship), and over 0.9 was a very high correlation (Inozemtseva and Holmes 2014).

The correlation between BW and body measurements is presented in Table 2. In the single predictor, the correlation between BW and CG is the highest (0.836) compared to $\mathrm{BL}$ and $\mathrm{WH}$. The highest correlation between $\mathrm{BW}$ and $\mathrm{CG}$ compared $\mathrm{BL}$ and $\mathrm{WH}$ were expressed on Cornigliese sheep (Sabbioni et al. 2020), blackhead Somali sheep (Feyissa et al. 2018), Mengali sheep (Eyduran et al. 2017), Kilakarsal sheep (Ravimurugan et al. 2013), Uda sheep (Yakubu 2012), Arsi Bale sheep (Worku 2019), male Afar goat (Tekle 2014), female Etawah Grade goat (Dakhlan et al. 2020) and Nguni cattle (Tyasi et al. 2020). The CG becomes the best predictor for BW on the livestock can be possible due to the $\mathrm{CG}$ development was aligned with the ribs, muscles, and fats development, where an increase in the proportion of carcass fat and rib-eye weight were related to the growth and fat accumulation (Dakhlan et al. 2020). The BW was predicted by three combinations of body measurements in multiple linear regression analysis: BL, CG, and WH (0.884). The correlation between BW and the combination of BL and $\mathrm{CG}$ also has a value that 
was similar to the combination of the three predictors, namely 0.884 . The multicollinearity test results for the BW regression model for all $\mathrm{BL}, \mathrm{CG}$, and $\mathrm{WH}$ combinations showed a tolerance value $>0.10$ and a VIF value $<10.00$, meaning no multicollinearity in the model (Daoud 2017).

\section{Regression models between body measurements and body weight}

The correlation analysis of body measurements of female Batur sheep not performed in a separate group of age but performed in separated body measurements as the predictor, namely single and combination. The regression equation of body measurement with the bodyweight of female Batur sheep shown in Table 2. The scatter plot and regression line of the regression model using three body measurements as a single predictor are shown in Figure 4. The best regression equation was chosen by the highest $r$, $\mathrm{R}^{2}$, and adjusted $\mathrm{R}^{2}$, and following by the lowest RSE, AIC, and BIC. The results in Table 2 indicated that using single body measurements as the predictor, CG was the best predictor for $\mathrm{BW}$ with the highest $\mathrm{r}(0.836), \mathrm{R}^{2}$ (0.750), and adjusted $\mathrm{R}^{2}$ (0.746) and the lowest RSE (8.73) AIC (568.639), and BIC (570.930). The CG as the best predictor compared to other body measurements as single predictors (BL and HW) was also supported by the Gaussian curve that showed the thickest line (Figure 5) with the greatest F-value and importance value (62.761 and $0.691)$ compared to BL (25.431 and 0.279) and HW (2.958 and 0.032). Testing with the automatic linear model with the best subsets method also showed that CG is in a more fit rank with the lowest information criterion (AICC) value (344.527) compared to BL (436.626) and WH (442.307). These results in line with the study on Wonosobo sheep (Haryanti et al. 2015), Arsi Bale sheep (Worku 2019), Kilakarsal sheep (Ravimurugan et al. 2013), blackhead Somali sheep (Feyissa et al. 2018), Sudanese Shogur sheep (Musa et al. 2012), Uda sheep (Yakubu 2012), Washera sheep, Farta sheep (Mekuriaw et al. 2013), indigenous Ethiopia sheep (Tesfay et al. 2017), Maefur goat (Berhe 2017) that CG is the most suitable body trait for reflecting and predicting body weight.

The formula for predicting BW with the combination of body measurements as the predictor showed that BL and $\mathrm{CG}$ were the best combinations as the predictor. The combination $\mathrm{BL}$ and $\mathrm{CG}$ have the highest value for $\mathrm{r}$ $(0.884), R^{2}(0.782)$, and adjusted $R^{2}(0.776)$. And, also has the lowest value for RSE (8.20), AIC (559.962), BIC (562.239), and AICC (335.796). The combination of BL and $\mathrm{CG}$ as the two best predictors for the BW was also reported and confirmed by Sabbioni et al. (2020) in male and female Cornigliese sheep, Haryanti et al. (2015) in Wonosobo sheep, Yilmaz et al. (2013) in Karya sheep and Dakhlan et al. $(2020 ; 2021)$ in female Etawah Grade goat and female Saburai goat. The accuracy was possible because CG was straight-linked to the chest and abdominal area, which dominates the volume of body weight from the chest to the base of the tail as known as BL (Dakhlan et al. 2020).

Table 2. Regression equation of body measurements with bodyweight of female Batur sheep

\begin{tabular}{|c|c|c|c|c|c|c|}
\hline Regression equations & $\mathbf{r}$ & $\mathbf{R}^{2}$ & Adj. $R^{2}$ & RSE & AIC & BIC \\
\hline $\mathrm{BW}=-17.210+1.191 \mathrm{BL}$ & $0.443 * *$ & 0.196 & 0.186 & 15.64 & 656.518 & 658.809 \\
\hline $\mathrm{BW}=-28.443+0.905 \mathrm{CG}$ & $0.836 * *$ & 0.750 & 0.746 & 8,73 & 568.639 & 570.930 \\
\hline $\mathrm{BW}=-3.385+1.094 \mathrm{WH}$ & $0.369 * *$ & 0.137 & 0.125 & 16.21 & 661.862 & 664.152 \\
\hline $\mathrm{BW}=-56.522+0.509 \mathrm{BL}+0.843 \mathrm{CG}$ & $0.884 * *$ & 0.782 & 0.776 & 8.20 & 559.962 & 562.239 \\
\hline $\mathrm{BW}=-55.287+1.010 \mathrm{BL}+0.825 \mathrm{WH}$ & $0.519 * *$ & 0.269 & 0.250 & 15.01 & 649.759 & 652.036 \\
\hline $\mathrm{BW}=-33.714+0.890 \mathrm{CG}+0.112 \mathrm{WH}$ & $0.866 * *$ & 0.751 & 0.744 & 8.77 & 569.818 & 572.095 \\
\hline $\mathrm{BW}=-57.897+0.505 \mathrm{BL}+0.839 \mathrm{CG}+0.034 \mathrm{WH}$ & $0.884 * *$ & 0.782 & 0.773 & 8.26 & 561.579 & 563.842 \\
\hline
\end{tabular}

Note: $* *$ Correlation is significant at the 0.01 level (2-tailed)

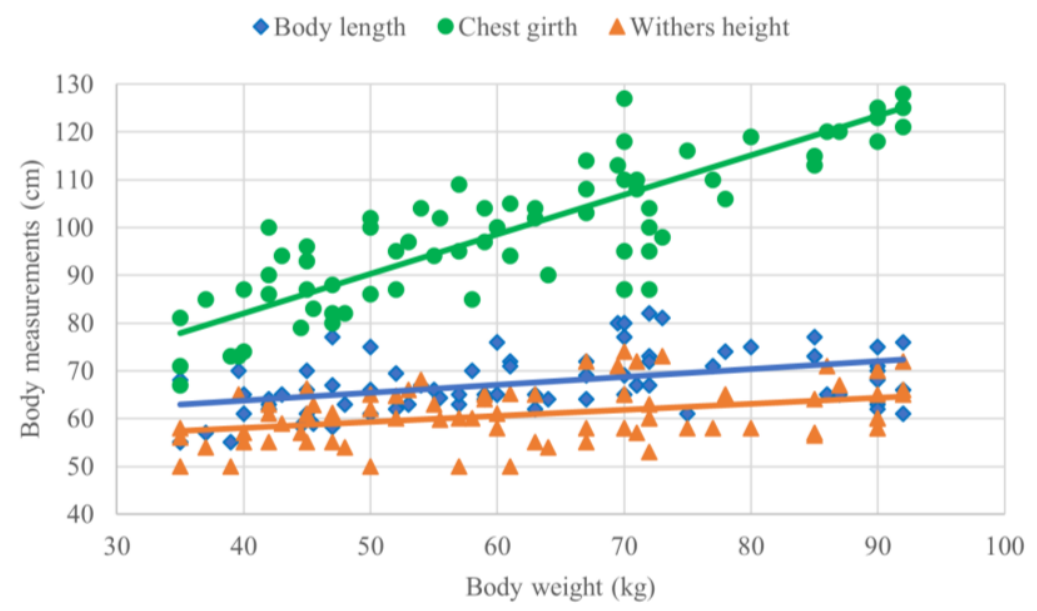

Figure 4. Scatter plot and regression line of body weight and three single predictors 


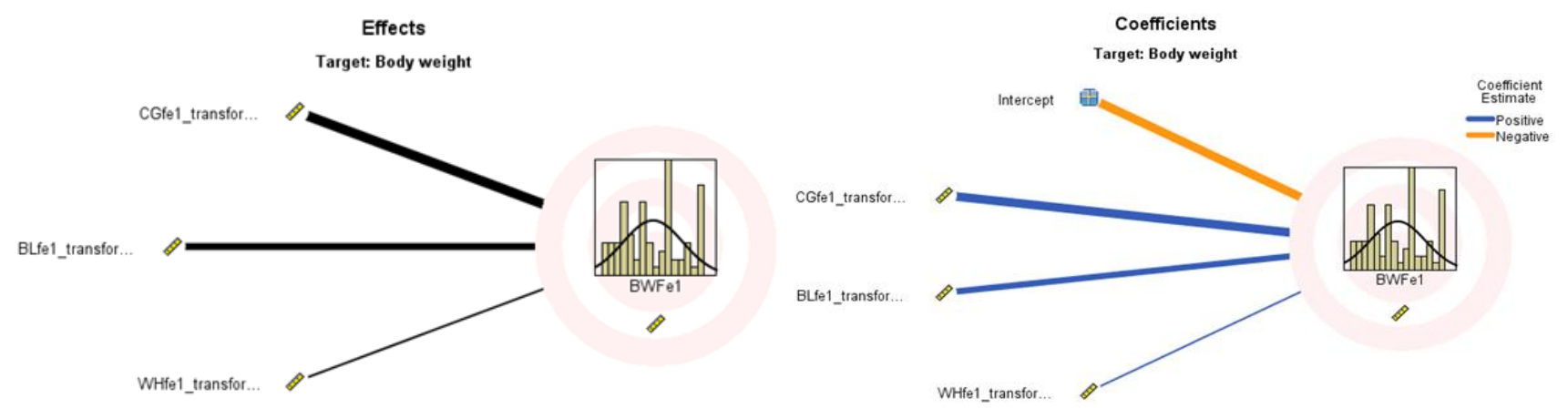

Figure 5. Best fit Gaussian curve (all predictors entered)

Table 3. Model building summary in automatic linear regression using the Best Subsets method

\begin{tabular}{|c|c|c|c|c|c|c|c|c|}
\hline \multirow{2}{*}{ Effect (transformed) } & \multicolumn{8}{|c|}{ Model } \\
\hline & 1 & 2 & 3 & 4 & 5 & 6 & 7 & 8 \\
\hline BL & $\sqrt{ }$ & $\sqrt{ }$ & & & $\sqrt{ }$ & $\sqrt{ }$ & & \\
\hline CG & $\sqrt{ }$ & $\sqrt{ }$ & $\sqrt{ }$ & $\sqrt{ }$ & & & & \\
\hline WH & & $\sqrt{ }$ & & $\sqrt{ }$ & $\sqrt{ }$ & & $\sqrt{ }$ & \\
\hline Information Criterion & 335.796 & 337.977 & 344.527 & 346.305 & 431.256 & 436.626 & 442.307 & 451.796 \\
\hline
\end{tabular}

Note: A checkmark means the effect is in the model.

Table 4. The model building summary in automatic linear regression using the Forward Stepwise method

\begin{tabular}{ccccc}
\hline Predictor & $\begin{array}{c}\text { Effect } \\
\text { (transformed) }\end{array}$ & $\begin{array}{c}\text { Information } \\
\text { Criterion }\end{array}$ & $\begin{array}{c}\text { Accuracy } \\
(\%)\end{array}$ & $\begin{array}{c}\text { Best's } \\
\text { rank }\end{array}$ \\
\hline 1 & CG & 344.527 & 74.6 & 2 \\
2 & CG+BL & 335.796 & 77.6 & 1 \\
\hline
\end{tabular}

Table 2 also indicated that combination of three body measurements (BL, CG, and $\mathrm{WH}$ ) as the predictor for $\mathrm{BW}$ similar with two best predictors (combination of $\mathrm{BL}$ and CG) with the highest value for $r(0.884), R^{2}(0.782)$, adjusted $\mathrm{R}^{2}(0.773)$, and also has the lowest value for RSE (8.26), AIC (561.579), BIC (563.842) compared to body measurements as the single and two combination predictors. The prediction of $\mathrm{BW}$ in female Batur sheep with a combination of BL and CG showed the best. It was supported by the results of automatic linear regression analysis using the best subsets method (Table 3) that showed the combination of BL and $\mathrm{CG}$, ranks first with the lowest AICC value, namely 346.305. It is also supported by the results of automatic linear regression analysis using the stepwise forward method (Table 4). The results of two models for BW prediction and the combination of BL and CG was the model with the highest accuracy (77.6\%) compared to the combination of CG $(74.6 \%)$ and CG as a single predictor $(64.1 \%)$. Each model can be used for the prediction of body weight with a different purpose. For simple use, for example, for marketing purposes and by farmers, a single predictor model can be used. For ruminant farmers, the live body weight is a critical factor in determining the selling price. They cannot weigh the cattle by digital weighing scale because most smallholder farmers do not have scales or good construction pens and sell ruminants in animal markets, where livestock scales are not available. Jakaria et al. (2019) stated that to date, cattle weight in traditional trading practice relies on estimation by traders without using scale. Haq et al. (2020) added that in Brebes District, Central Java, the Jabres cattle farmers estimated and predicted the BW of their cattle only by eyebased assessment or called "jogrog" method for determining the cattle price. The inaccuracy in predicting body weight lowers the bargaining position of the smallholder farmers so that profits are not optimal. A more accurate live body weight prediction method was needed to help smallholder farmers reach the right cattle price. As an alternative method in predicting live body weight, a regression equation model with a single prediction of $\mathrm{CG}$ can be used. The easy way to apply is to make a CG conversion using a measuring tape to the sheep's body weight. So that smallholder farmers do not need to weigh their sheep, body weight can be estimated only by measuring $\mathrm{CG}$.

Thus, smallholder farmers can determine the selling price of their sheep in the market. This study indicated that $\mathrm{CG}$ is the best and most accurate single predictor of $\mathrm{BW}$ for Batur sheep. As well as to other local Indonesian cattle such as Ongole Crossbred cattle (Paputungan et al. 2013), Aceh cattle (Putra et al. 2014), Simental-Ongole Crossbred cattle (Suliani et al. 2017), Bali cattle (Jakaria et al. 2019), Jabres cows (Haq et al. 2020), Etawah Peranakan goats (Dahklan et al. 2020), Kacang goats (Depison et al. 2020), Saburai goats (Dakhlan et al. 2021). For the breeding purpose or evaluation of growth and productivity performance can use a more precise model with a combination of several variables (Taye et al. 2016). With the decline of the Batur sheep population and once the local government's efforts to increase the population of Batur sheep. Genetic improvement in Batur sheep could be conducted using body measurements such as chest girth and body length used as indirect selection criteria (Jakaria 
et al. 2019). Sing the combination of CG and BL could enhance accuracy in estimating the live BW of Batur sheep and also be used for genetic selection to enhance Batur sheep growth performance (Dakhlan et al. 2020; Waheed et al. 2020).

In conclusion, body measurements can be used as a predictor to estimate body weight. The best and accurate prediction of BW in female Batur sheep was obtained by a combination of two body measurements, namely a combination of $\mathrm{CG}$ and $\mathrm{BL}(\mathrm{BW}=-56.522+0.509 \mathrm{BL}+$ $0.843 \mathrm{CG})$. Chest girth (BW $=-28.443+0.905 \mathrm{CG})$ was also found as the best single predictor of BW for female Batur sheep and possible to apply for Batur sheep farmers.

\section{ACKNOWLEDGEMENTS}

The authors are thankful to the Director-General of Higher Education, Ministry of Education and Culture of the Republic of Indonesia, for funding this study with the PMDSU (Grant No. 27/E1/KPT/2020 with contract no. 3175/UN1.DITLIT/DIT-LIT/PT/2020). The authors also thank the Faculty of Veterinary Medicine Universitas Gadjah Mada and the Department of Agriculture, Fisheries, and Animal Husbandry of Banjarnegara District for supporting and thank all farmers.

\section{REFERENCES}

Abdel-Mageed I, Ghanem N. 2013. Predicting body weight and longissimus muscle area using body measurements in subtropical goat kids. Egypt J Sheep Goat Sci 8: 95-100. DOI: 10.12816/0005029.

Abera B, Kebede K, Gizaw S, Feyera T. 2014. On-farm phenotypic characterization of indigenous sheep types in Selale Area, Centra Ethiopia. Vet Sci Technol 5: 1-6. DOI: 10.4172/2157-7579.1000180.

Arsalan M, Ullah MA, Waheed A. 2021. Morphological indices and simple regression to predict live body weight from morphological traits of indigenous sheep. Pak $\mathrm{J}$ Zool 53: 1-4. DOI: 10.17582/journal.pjz/20190226030231.

Berhe WG. 2017. Relationship and prediction of body weight from morphometric traits in Maefur goat population in Tigray, Northern Ethiopia. J Biom Biostat 08: 1000370. DOI: 10.4172/21556180.1000370 .

Central Bureau of Statistics. 2016. Statistics of Batur Sub-district 2016 Central Bureau of Statistics of Banjarnegara District, Banjarnegara.

Cleophas TJ, Zwinderman AH. 2016. SPSS for Starters and 2nd Levelers. 2nd ed. Springer Science and Business Media, Inc, Lyron, France. DOI: 10.1007/978-3-319-20600-4.

Dakhlan A, Hamdani MDI, Putri DR, Sulastri, Qisthon A.. 2021. Short Communication: Prediction of body weight based on body measurements in female Saburai goat. Biodiversitas 22: 1391-1396. DOI: $10.13057 /$ biodiv/d220341.

Dakhlan A, Saputra A, Hamdani MDI, Sulastri. 2020. Regression models and correlation analysis for predicting body weight of female Ettawa grade goat using its body measurements. Adv Anim Vet Sci Regres 8 : 1142-1146. DOI: 10.17582/journal.aavs/2020/8.11.1142.1146.

Daoud JI. 2017. Multicollinearity and regression analysis. IOP Conf Ser J Phys 949: 012009. DOI: 10.1088/1742-6596/949/1/012009.

Department of Agriculture Fisheries and Animal Husbandry. 2019. The Recapitulation and Data Collection of Batur Sheep. Department of Agriculture, Fisheries and Animal Husbandry of Banjarnegara District, Banjarnegara. [Indonesian]

Depison D, Putra WPB, Gushairiyanto G, Alwi Y, Suryani H. 2020 Morphometric characterization of Kacang goats raised in lowland and highland areas of Jambi Province, Indonesia. J Adv Vet Anim Res 7: 734-743. DOI: $10.5455 /$ javar.2020.g475.
Eteqadi B, Hossein-Zadeh NG, Shadparvar AA. 2014. Population structure and inbreeding effects on body weight traits of Guilan sheep in Iran. Small Rum Res 119: 45-51. DOI: 10.1016/j.smallrumres.2014.03.003.

Eyduran E, Akkus O, Kara MK, Tirink C, Tariq MM. 2017. Use of multivariate adaptive regression splines (mars) in predicting body weight from body measurements in Mengali rams. In: International Conference on Agriculture, Forest, Food Science and Technologies, Cappadocia, 15-17 May 2017.

Feyissa AA, Kefeni KK, Amaha N. 2018. Application of body measurements of blackhead Somali sheep as parameters for estimation of live weight. Iran J Appl Anim Sci 8: 647-652.

Ghahri B, Alijani S, Rafat SA, Nabavi R, Daghigh KH. 2019. Genetic appraisal of growth traits in Iranian native Ghezel sheep using random regression models. Turkish J Vet Anim Sci 43: 372-379. DOI: 10.3906/vet-1704-73.

Hailu A, Mustefa A, Asegede T, Assefa A, Sinkie S, Tsewene S. 2020. Phenotypic characterization of sheep populations in Tahtay Maichew district, Northern Ethiopia. Genet Resour 1: 12-22. DOI: 10.46265/genresj.shbd3744.

Haq MS, Budisatria IGS, Panjono P, Maharani D. 2020. Prediction of live body weight using body measurements for Jawa Brebes (Jabres) Cattle. J Anim Plant Sci 30: 552-559. DOI: 10.36899/JAPS.2020.3.0065.

Haren HIH, Saleh DM, Sumaryadi MY, Purwantini D, Prayitno. 2018. Morphometric traits and body weight at different age of Batur sheep in Banjarnegara. In: Proceeding of The $4^{\text {th }}$ National Seminar on Animal Science and Technology: Development of Local Livestock Genetic Resources Towards Self-Sufficiency in Food ASUH, Faculty of Animal Science, Jenderal Soedirman University, Purwokerto, 7 Juli 2018

Haryanti Y, Kurnianto E, Lestari CMS. 2015. Estimation of body weight using body measurements on Wonosobo sheep. J Sain Peternak Indones 10: 1-6. DOI: 10.31186/jspi.id.10.1.1-6. [Indonesian]

Hossein-Zadeh NG. 2012. Inbreeding effects on body weight traits of Iranian Moghani sheep. Arch Anim Breed 55: 171-178. DOI: 10.5194/aab-55-171-2012.

Ibrahim A, Budisatria IGS, Widayanti R, Artama WT. 2019a. The impact of religious festivals on roadside livestock traders in urban and periurban areas of Yogyakarta, Indonesia. Vet World 12: 1408-1415. DOI: 10/14202/vetworld.2019.1408-1415.

Ibrahim A, Budisatria IGS, Widayanti R, Artama WT. 2019b. Consumer's preferences for sheep attributes for Eid al-Adha celebration in Yogyakarta, Indonesia. IOP Conf Ser Earth Environ Sci 387: 012001. DOI: 10.1088/1755-1315/387/1/012001.

Ibrahim A, Budisatria IGS, Widayanti R, Artama WT. 2020a. The genetic profiles and maternal origin of local sheep breeds on Java Island (Indonesia) based on complete mitochondrial DNA D-loop sequences. Vet World 13: 2625-2634. DOI: 10.14202/vetworld.2020.2625-2634.

Ibrahim A, Budisatria IGS, Widayanti R, Atmoko BA, Yuniawan R, Artama WT. 2020b. On-farm body measurements and evaluation of Batur Sheep on different age and sex in Banjarnegara District, Indonesia. Adv Anim Vet Sci 8: 1028-1033. DOI: 10.17582/journal.aavs/2020/8.10.1028.1033.

Inozemtseva L, Holmes R. 2014. Coverage is not strongly correlated with test suite effectiveness. Proc-Int Conf Softw Eng 435-445. DOI: 10.1145/2568225.2568271.

Iqbal F, Ali M, Huma ZE, Raziq A. 2019. Predicting live body weight of Harnai sheep through penalized regression models. J Anim Plant Sci 29: 1541-1548.

Jafari S, Hashemi A. 2014. Estimation of genetic parameters for body measurements and their association with yearling liveweight in the Makuie sheep breed. S Afr J Anim Sci 44: 140. DOI: 10.4314/sajas.v44i2.6.

Jakaria J, Sutikno, Ulum MF, Priyanto R. 2019. Live body weight assessment based on body measurements in Bali cattle (Bos javanicus) at extensive rearing system. Pakistan J Life Soc Sci 17: 1723.

Kefale A, Awoke T, Getu A, Abegaz S. 2017. On-farm phenotypic characterization of Holla sheep types in South Wollo Zone Eastern Amhara Ethiopia. Online J Anim Feed Res 7: 113-123.

Khan MA,Tariq MM, Eyduran E, Tatliyer A, Rafeeq M, Abbas F, Rashid N, Awan MA, Javed K. 2014. Estimating body weight from several body measurements in Harnai sheep without multicollinearity problem. J Anim Plant Sci 24: 120-126. 
Koc Y, Eyduran E, Akbulut O. 2017. Application of regression tree method for different data from animal science. Pak J Zool 49: 599607. DOI: 10.17582/journal.pjz/2017.49.2.599.607.

Lavery MR, Acharya P, Sivo SA, Xu L. 2017. Number of predictors and multicollinearity: What are their effects on error and bias in regression? Commun Stat-Simul Comput 48(9): 1-25. DOI: 10.1080/03610918.2017.1371750.

Mahmud MA, Shaba P, Abdulsalam W, Yisa HY, Gana J, Ndagi S, Ndagimba R. 2014. Live body weight estimation using cannon bone length and other body linear measurements in Nigerian breeds of sheep. J Adv Vet Anim Res 1: 169-176. DOI: 10.5455/javar.2014.a29.

Mavule BS, Muchenje V, Bezuidenhout CC, Kunene NW. 2013 Morphological structure of Zulu sheep based on principal component analysis of body measurements. Small Rum Res 111: 23-30. DOI 10.1016/j.smallrumres.2012.09.008.

Mekuriaw S, Mekuriaw Z, Taye M, Mekuriaw G, Amane A, Bimrew T, Haile A. 2013. Growth performance and linear body measurements of Washera, Farta and their crossbreed sheep under farmers management system in Western Highland of Amhara Region. Sci J Vet Adv 2: 132-143.

Ministry of Agriculture. 2011. Decree of the Minister of Agriculture of The Republic of Indonesia No. 2916/Kpts/OT.140/6/2011 on the Establishment of the Batur Sheep Breed. Ministry of Agriculture of the Republic of Indonesia, Jakarta, Indonesia.

Mohammad MT, Rafeeq M, Bajwa MA, Awan MA, Abbas F, Waheed A Bukhari FA, Akhtar P. 2012. Prediction of body weight from body measurements using Regression Tree (RT) method for indigenous sheep breeds in Balochistan, Pakistan. J Anim Plant Sci 22: 20-24

Mulyono RH, Sumantri C, Noor RR, Jakaria, Astuti DA. 2018. The prediction of prolificacy using linear body parameters and craniometric analysis in Etawah-grade does. Trop Anim Sci J 41: 77 84. DOI: $10.5398 /$ tasj.2018.41.2.77

Muryanto, Kurnianto H, Malik A. 2019. Potential, problems and alternatives for the conservation and development of Batur sheep. In Proceedings of the National Seminar on Agricultural Resource Readiness and Location-Specific Innovation Entering the Industrial Era 4.0, Semarang, 9 October 2019. [Indonesian]

Musa AM, Idam NZ, Elamin KM. 2012. Heart girth reflect live body weight in Sudanese Shogur Sheep under field conditions. World Vet J 2: 54-56.

Paputungan U, Hakim L, Ciptadi G, Lapian HFN. 2013. The estimation accuracy of live weight from metric body measurements in Ongole grade cows. J Indones Trop Anim Agric 38: 149-155. DOI: 10.14710/jitaa.38.3.149-155.

Putra WPB, Sumadi, Hartatik T. 2014. the estimation of body weight of Aceh cattle using some measurements of body dimension. J Ilmu dan Teknol Peternak 3: 76-80. [Indonesian]

Rather MA, Bashir I, Hamdani A, Khan NN, Ahangar SA, Nazki M. 2021. Prediction of body weight from linear body measurements in Kashmir Merino sheep. Adv Anim Vet Sci 9: 189-193. DOI: 10.17582/journal.aavs/2021/9.2.189.193.

Ravimurugan T, Thiruvenkadan AK, Sudhakar K, Panneerselvam S, Elango A. 2013. The estimation of body weight from body measurements in Kilakarsal sheep of Tamil Nadu, India. Iran J Appl Anim Sci 3: 357-360.

Rohayati T, Herawati E. 2020. Identification of body sizes on fight Garut ram in arena agility sheep Rancabango Garut District. J Anim Husb Sci 4: 47-53. DOI: 10.52434/janhus.v4i2.976.

Ruangwittayanusorn K, Promket D, Chumpawadee S, Muapkunton J, Sriboon O, Pukkawan K. 2019. Using beef morphology to predict carcass weight which cutting in Thai-Isaan style. Int J Geomate 17 : 65-70. DOI: 10.21660/2019.62.4801.

Sabbioni A, Beretti V, Superchi P, Ablondi M. 2020. Bodyweight estimation from body measures in Cornigliese sheep breed. Ital $\mathbf{J}$ Anim Sci 19: 25-30. DOI: 10.1080/1828051X.2019.1689189.

Saghi DA, Shahdadi AR, Borzelabad FK, Mohammadi K. 2018. Estimates of covariance functions for growth of Kordi sheep in Iran using random regression models. Small Rum Res 162: 69-76. DOI: 10.1016/j.smallrumres.2018.03.007.

Shirzeyli FH, Lavvaf A, Asadi A. 2013. Estimation of body weight from body measurements in four breeds of Iranian sheep. Songklanakarin J Sci Technol 35: 507-511.

Sodiq A, Yuwono P, Santosa SA. 2011. Litter size and lamb survivability of Batur sheep in upland areas of Banjarnegara District, Indonesia. Anim Prod 13: 166-172.

Suliani S, Pramono A, Riyanto J, Prastowo S. 2017. The relationship between body size and body weight of male Simmental-Ongole crossbred at various age in Jagalan Surakarta Abattoir. Sains Peternak 15: 16. DOI: 10.20961/sainspet.v15i1.4998. [Indonesian]

Tariq MM, Iqbal F, Eyduran E, Bajwa MA, Huma ZE, Waheed A. 2013. Comparison of non-linear functions to describe the growth in Mengali sheep breed of Balochistan. Pak J Zool 45: 661-665.

Taye M, Yilma M, Rischkowsky B, Dessie T, Okeyo M, Mekuriaw G, Haile A. 2016. Morphological characteristics and linear body measurements of Doyogena sheep in Doyogena district of SNNPR, Ethiopia. African J Agric Res 11: 4873-4885. DOI: 10.5897/ajar2016.11826.

Tekle T. 2014. Predicting live weight using body measurements in Afar goates in North-Eastern Ethiopia. Momona Ethiop J Sci 6: 18. DOI: 10.4314/mejs.v6i2.109619.

Tesfay HH, Banerjee AK, Mummed YY. 2017. Live body weight and linear body measurements of indigenous sheep population in their production system for developing suitable selection criteria in Central Zone of Tigray, Northern Ethiopia. African J Agric Res 12: 10871095. DOI: 10.5897/ajar2016.11927.

Tyasi T, Mathye N, Danguru L, Rashijane L, Mokoena K, Makgowo K, Mathapo M, Molabe K, Bopape P, Maluleke D. 2020. Correlation and path analysis of body weight and biometric traits of Nguni cattle breed. J Adv Vet Anim Res 7: 148. DOI: 10.5455/javar.2020.g404.

Udo HMJ, Budisatria IGS. 2011. Fat-tailed sheep in Indonesia: An essential resource for smallholders. Trop Anim Health Prod 43(7): 1411-1418. DOI: 10.1007/s11250-011-9872-7.

Ullah MA, Amin M, Abbas MA. 2013. Non-linear regression models to predict the lamb and sheep weight growth. Pakistan J Nutr 12: 865869. DOI: $10.3923 /$ pjn.2013.865.869.

Waheed HM, Moaeen-Ud-din M, Khan MS, Saif-Ur-rehman M, NawazUl-rehman MS. 2020. Prediction of monthly body weight from body measurements in Beetal goats reared under field and farm conditions. J Anim Plant Sci 30: 25-31. DOI: 10.36899/JAPS.2020.1.0003.

Worku A. 2019. Bodyweight had highest correlation coefficient with heart girth around the chest under the same farmers feeding conditions for Arsi Bale sheep. Int J Agric Sci Food Technol 5: 6-12. DOI: $10.17352 / 2455-815 X .000035$.

Yakubu A. 2012. Application of regression tree methodology in predicting the bodyweight of Uda sheep. Sci Pap Anim Sci Biotechnol 45(2): 484-490.

Yilmaz O, Cemal I, Karaca O. 2013. Estimation of mature live weight using somebody measurements in Karya sheep. Trop Anim Health Prod 45: 397-403. DOI: 10.1007/s11250-012-0229-7. 